Article

\title{
'Some Animals Are More Equal Than Others': The Hierarchy of Citizenship in Austria
}

\section{Suleman Lazarus (1)}

School of Humanities and Social Sciences, University of Greenwich, Park Row, London SE10 9LS, UK; suleman.lazarus@gmail.com

Received: 22 April 2019; Accepted: 8 July 2019; Published: 16 July 2019

\begin{abstract}
While this article aims to explore the connections between citizenship and 'race', it is the first study to use fictional tools as a sociological resource in exemplifying the deviation between citizenship in principle and practice in an Austrian context. The study involves interviews with 73 Austrians from three ethnic/racial groups, which were subjected to a directed approach to qualitative content analysis and coded based on sentences from George Orwell's fictional book, 'Animal Farm'. By using fiction as a conceptual and analytical device, this article goes beyond the orthodox particulars of citizenship to expose the compressed entitlements of some racial/ethnic minorities. In particular, data analysis revealed two related and intertwined central themes: (a) "all animals are not equal or comrades"; and (b) "some animals are more equal than others". All 'animals' may be equal in principle, whereas, in practice, their 'race' serves as a critical source of social (dis)advantage in the 'animal kingdom'. Thus, since citizenship is a precondition for possessing certain rights that non-citizens are not granted, I argue that citizenship cannot only be judged by whom it, in theory, excludes (i.e., non-citizens), but also by how it treats the included (i.e., citizens) on the basis of their 'race'. I conclude that skin colour is a specific aspect of the hierarchy of citizenship in Austria, which reinforces that 'some animals are more equal than others'.
\end{abstract}

Keywords: Austria; citizenship; fiction and social reality; social citizenship; 'race'; ethnic groups; animal farm; racism in Austria; inequalities; social hierarchy

\section{Introduction}

'No one believes more firmly than Comrade Napoleon that all animals are equal.'

-George Orwell.

Literature is a privileged way of illuminating social relations and locating the social sciences among the humanities (Redfield 1962; Longo 2015). This article is broadly based on the premise that all 'animals' may or may not be equal in principle, but their perceived physical differences are critical sources of social advantage and disadvantage in all 'animal kingdoms'. This strategy resonates with the view that multiple manifestations of (dis)advantages in many parts of the world have connections with racial forces (Alexander 2012; Gilroy 1987; Forsyth et al. 2013; Hazard 2011; Hipp and Kubrin 2017; Pepper 2017; Tynes et al. 2016). As many social scientists have noted, 'race' is a social construct, and much of 'reality' is socially constructed (e.g., Burt et al. 2012; Fogiel-Bijaoui 2016; Ghafournia and Easteal 2018; Graber 2019; Hazard 2011; Hipp and Kubrin 2017; Tynes et al. 2016; UNESCO 1969). While there is a general consensus that racial groups do not exist (e.g., Banton 1998), it is, however, indisputable that 'race' has enduring real-life consequences (Agozino 2018; Burt et al. 2012; Graber 2019; Pepper 2017; Tynes et al. 2016). It is also undeniable that its persistence as a stratifying feature of societies is to some degree universalisable (Alexander 2012; Wolfe 2017; Tynes et al. 2016; UNESCO 1969). Because 'race' is a critical stratifying feature of societies, it concomitantly serves as a constant 
reminder that racism is unlikely to evaporate into thin air (Philips and Platt 2016; UNESCO 1969). In this respect, racism can be understood as a relational process by which superiority that inheres to some group is predominantly directed to those categorised as originating from Western nations (including Austria) at the expense of the rest (e.g., people originating from Africa, Asia, Latin America) (e.g., Philips and Platt 2016; UNESCO 1969).

In an Austrian context, there is a tag game similar to 'What's the time, Mr Wolf?' In this playground game, the lead player would ask, 'Who is scared of a black man?' And other children would chorus, 'Nobody!' Then the leader would ask again, 'And when he comes?' and others would reply, 'We run away!' Storytelling is deemed appropriate in issues that concern individuals' 'race' and their citizenry entitlements (Byerman 2019; Ladson-Billings 2010) and human intercourses in general (Byerman 2019; Carr 2008). As Glenn (2009) and Ladson-Billings (2010) specifically pointed out, the eligibility for all citizenry entitlements, are broadly defined in racial terms. The non-official eligibility for citizenry entitlements supports the assumption that there is a notable deviation between the official rhetoric of citizenship and the lived realities of ethnic minorities in Austrian society.

In light of the Austrian tag game, whilst human societies are shaped and re-shaped by diverse forces (Gonzales Rose 2017; Ibrahim 2015), belonging to a society as a citizen is a multi-faceted experience and varies according to the particularities of individuals (Dahlstedt et al. 2017; Glenn 2009; Gilroy 1987). The multiple axes upon which societal communities are formed thereby acknowledge that there is no singular model of citizenship (Akrivopoulou 2013; Domingues 2017). Paradoxically, mere acquisition of a passport automatically gives the holder certain formal rights and juridical status on a surface level (Dahlstedt et al. 2017), whereas entitlement to certain civic rights and social citizenship is graded according to different axes of differentiations such as 'race' (Glenn 2009; Anderson 2013; Tynes et al. 2016), sexuality (Stambolis-Ruhstorfer 2013; Triger 2012), age (Rush and Lazarus 2018; Warming 2019) and gender (Lazarus et al. 2017; Lavee and Benjamin 2017; Vacchelli and Kofman 2017). One might be inclined to point out that while citizenship intersects with 'race', it also interacts with multiple other categories such as class, gender and sexuality (Akrivopoulou 2013; Brubaker 1992; Fogiel-Bijaoui 2016; Triger 2012). These intersections consequently, have implications for this article's positioning.

Here, this present research admits that the intersections of the multiple categories involved in the analysis of citizenship are many and complex (due to its scope). Thus, the article mostly focuses on citizenship and 'race' connections (see also the focus of Ladson-Billings 2010, pp. 14-15 article and Lazarus 2019a, p. 2 work, based on a similar reason). The article, therefore, asks: "what are the narratives of racial minorities in Austria (blacks, Turkish, Germans) concerning their citizenship entitlements?" The present study aims to highlight that, as regards the entitlement to civic rights and social citizenship, certain minority Austrian citizens (or Austrians from 'immigrant backgrounds' e.g., Hipfl and Gronold 2011) are better off than others and are hierarchically graded based on 'race'. Equally, whilst this article will draw on hereditary (e.g., skin colour) rather than cultural (e.g., dress codes) axes of ethnic and racial differences, as a consequence, both 'ethnic' and 'racial' differences will be used interchangeably. This article uses Austria as an exemplary social context to draw attention to a colour-graded hierarchy of citizenship. Particularly, in exploring the theory of citizenship, this article takes the position that citizenship is not inherent or static and that a person's citizenry entitlements may be 'questioned' based on their ethnicity or/and 'race'. Henceforth, the sections of the article are sequentially presented as follows: theoretical framework, literature review, method, findings, discussion and conclusion.

\section{Theoretical Framework}

\subsection{Citizenship}

What is citizenship? If you asked a 'Professor of Citizenship', you would often receive the following sort of response: 'citizenship is mostly a formal and somewhat abstract way of conferring rights and including individuals within the state. It has, however, a substantive aspect, or at least that 
is what we sometimes find in the literature, according to which the status of someone in relation to society is more broadly construed than merely rights entitlements being at stake'. While this seems to be undeniable, there is a lot of tension between the formal rights aspect of citizenship and that broader framework. Whilst the term 'citizenship' was historically coined in Ancient Greece (Akrivopoulou 2013; Brubaker 1992), Marshall's (1950) work in Britain was a significant starting point for the development of citizenship and welfare studies (see also Marshall and Bottomore 1992). Citizenship has been at the forefront of struggles for freedom, democracy, and social rights (Domingues 2017). In part, the deviation between citizenship in principle and in practice is not only enormous; it is systematically biased against the powerless on the axes of 'race' (Alexander 2012; Wolfe 2017), class (Perchinig and Troger 1990; Platt 2016), religion (Permoser and Rosenberger 2016; Torry 2016) and gender (Aburabia 2017; Lavee and Benjamin 2017; Lazarus et al. 2017). For Marshall (1950), citizenship is comprised of social, political and civic rights and Marshall and Bottomore (1992, p. 17) defined citizenship as:

a status bestowed on those who are full members of a community. All who possesses the status are equal with respect to the rights and duties which with the status is endowed. There is no universal principle that determines what those rights and duties shall be, but societies in which citizenship is a developing institution create an image of an ideal citizenship against which achievement can be measured and towards which aspiration can be directed. The urge forward along the path thus plotted is an urge towards a fuller measure of equality, an enrichment of the stuff of which the status is made and an increase in the number of those on whom the status is bestowed.

Citizenship, in line with Marshall's (1950) theory, is the right to have social, political, and civic rights. Drawing from Marshall (1950), Glenn (2009, p. 19) recounted that the notion that civil rights are 'the rights necessary for individual freedom' which include freedom of religion, speech and thought, as well as the right to justice. Political rights are the rights necessary to participate in the governance of the community such as the right to vote, whereas social citizenship or the ability to live the life of a civilized being according to the standards prevailing in the society. If all three are present in a citizen's package, then that individual is said to have a full or complete citizenship (see also Bellamy 2008; Shutes 2016).

At the same time, citizenship is constituted of formal as well as substantive aspects (Marshall and Bottomore 1992). Whilst the formal aspect is concerned with the legal rights of citizens, for example, owning a passport or voting in elections, the substantive component is concerned with the broader contested and negotiated processes of exclusion and inclusion. These are the critical sources of social advantage and disadvantage that comprise the everyday reality of citizenship (Dahlstedt and Vesterberg 2017). Marshall's (1950) social, political and civic rights are not dichotomized according to 'in-group' and 'out-group' categories. On the contrary, migrants are granted a complex mix of civic, political, and social rights. Based on the axis of class, working class citizens could gradually attain relatively equivalent civil rights to those of middle- or upper-class citizens (see also Marshall and Bottomore 1992).

Unlike Marshall and Bottomore (1992) and Marshall (1950), who almost exclusively concentrated on the class component of citizenship, subsequent scholarship (Akrivopoulou 2013; Brubaker 1992) has indicated there are numerous other critical axes of citizenship, including 'race', class, religion, sexuality and gender as mentioned. Drawing on Ferrajoli's (2001) work on citizenry entitlements, Dahlstedt and Vesterberg $(2017$, p. 4) pointed out that citizenship is a precondition for possessing certain rights that non-citizens are not granted. 'Thus citizenship could be seen as an on-going formation of citizens as subjects-it is in a flux and never in a static mode. In other words, citizens are constantly in the making, they are made and the process involves a complex power relation'. For Akrivopoulou (2013, p. 138), citizenship could be conceptualized within a tripartite framework of membership, status, and equal rights (see also Brubaker 1992). It 'is a condition of civic equality [and] consists of membership of a political community where all citizens can determine the terms of social cooperation on an equal basis'. However, today's reality (e.g., globalization) dictates that an individual's capacity to benefit from the 
three elements that come with possession of a formal passport is dependent upon many factors that intersect with citizenship.

As a result of the intersectionality of the aforementioned factors such as 'race', ethnicity and class, citizenship can be conceptualized as being formed at the 'intersection between a number of different social relations or dimensions of super- and subordination' (Dahlstedt et al. 2017, p. 6). These intersections (e.g., 'race', class and citizenship) are implicated in giving rise to different forms of racialization (e.g., Colombo and Rebughini 2016). This present article focuses principally on the intersection of citizenship and ethnic/racial groups, in accordance with some other authors who have recently drawn the same connections (e.g., Ladson-Billings 2010). Regarding the differentiation of rights in connection with racialized discourses, insights from Malkki (1997) and Dahlstedt and Vesterberg's (2017) work suggest that becoming a full member of the societal community depends mainly upon the notion of imagined community. Certain members are considered to belong to the society, whereas others are regarded as strangers (reordered) due to their 'immigrant' background predominantly those whose racial characteristics differ from the majority. Therefore, as Favell $(1998$, p. 211) contended, the position of 'immigrant-citizens' within society reflects the overarching hegemonies that operate in the liberal democratic state, a political construct, which has historically relied upon 'national/cultural sameness to deliver its ideal principles of equality and tolerance in practice'.

Arguably, Marshall's theory of citizenship is situated in the particular British context, which was 'an empire with an extensive history of colonization and ethnic diversity'. Correspondingly, according to this theory of citizenship, black people never held the status of citizens since they were not perceived to be adequate members of the community (Dahlstedt et al. 2017, p. 7). In a similar vein, Anderson (2013) has since posited that 'immigrant-citizens' transcend traditional definitions of citizenship, occupying a grey area, because while migrants can legally hold citizen status, they may be defined socially as second class citizens within the public discourse (see also Brubaker 1992; Gilroy 1987). Therefore, it is reasonable to support Burt et al.'s (2012) and Wolfe's (2017) viewpoint that 'race' is a relational marker of civic entitlement. This suggests that the over-reliance on citizenship simply as the 'right to have rights', as suggested by Marshall (1950) tends to mask racialized practices, disproportionately bestowed on certain ethnic groups in relation to others. As a consequence, a brief comment on the relationship between 'race' and citizenship is necessary.

\subsection{Citizenship and 'Race' Connection}

Whilst the concept of 'race' is at the core of collective inequality, citizenship in principle is concerned with citizens' equality. Nonetheless, to dismiss a closer look at the above differences between citizenship and 'race' is most likely to omit a fuller understanding of the basis for their compatibility. In accordance with Wolfe's (2017, p. 3) conceptualisation, 'the concepts of race and citizenship have varied considerably across time and space, race has generally operated to reconcile the contradictions between official rhetoric of citizenship and the practical perpetuation of social inequality'. This article agrees with Wolfe's (2017) position that 'race' reinstated the social inequality that citizenship has theoretically aimed to dismantle.

Whilst there may be different 'shades' of whiteness, Austria is predominantly white. As a consequence, various stripes of racial minorities such as the Turkish and the blacks are perceived as the 'Other'. In this connection, 'race' is differentiated fundamentally between indigenous Austrians and the rest who, historically, through migration became citizens of Austria (Hipfl and Gronold 2011). In part, whiteness has been synonymous with Austrian citizenship (at least according to certain populist claims) (Refaie 2001; Hipfl and Gronold 2011). Whilst whiteness has historically been formed in opposition to non-whites (Hazard 2011; Burt et al. 2012; Graber 2019), citizenship has historically been created to differentiate between citizens and non-citizens (Shutes 2016; Glenn 2009). Consequently, Shutes (2016) specifically noted that the citizenry entitlements of a particular ethnic group are most evident if compared to the advantage of other groups; through relational processes. 
Relational processes commonly situate minority racial/ethnic groups as inferior (immigrant-citizens) and position the majority as superior in terms as their citizenry entitlements. Citizenship in practice is most vulnerable to discrimination unlike citizenship in theory. The two groups are generally located at the opposite end of a continuum (the Self and the Other) (Ladson-Billings 2010; Glenn 2009; Shutes 2016). The critical point is that while citizenship and 'race' are products of social constructions, the connections between them have real life consequences. Simply put, they are systematically influenced to protect the rights and privileges of those in power at the expense of the powerless (e.g., through racist practices) (Shutes 2016; Glenn 2009; Hazard 2011; UNESCO 1969). It is reasonable therefore to acknowledge that despite the seeming differences between citizenship and 'race', they both embody unequal power resources, contestable and exercisable in varying degrees across nations. Here, it would not be a stretch to suggest that the reconciliation of the differences between the concept of citizenship and 'race' is reminiscent of Mills' ([1959] 2000) conceptualisation of sociological imagination. For Mills ([1959] 2000), the sociological imagination is the awareness of the connections between personal experiences and society more broadly. In addition to the above insight, for this article, sociological imagination involves the awareness of the compatibilities between literary text (e.g., fiction, poetry) and sociological analysis of data. Thus, this article appreciates insights from literary works as sociological recourses.

\subsection{Fiction and Social Reality: Austria}

While it may seem strange to some modern sociologists, as Longo (2015, p. 56) and Cappetti (1993, p. 32) observed, 'traces of sociological applications of literary works as tools for a better understanding of human reality' were common-place a long time ago (e.g., Park and Burgess 1921). This article builds on early sociologists ${ }^{1}$ who have endorsed the suitability of subjecting literary sources to sociological analysis and imagination (Park and Burgess 1921; Znaniecki 1934; Farrell 1954; Redfield 1962). In exploring the utility of fiction as a sociological resource, insights from a fictional book, in this case, Orwell's (1955), "Animal Farm" are deemed appropriate (Polkinghorne 1988; Gibson 2007) because the process of their inclusion is sociologically outlined (Toscano 2011). Firstly, this article acknowledges that the book as a whole (Animal Farm) is primarily about the rise of 'totalitarianism' (i.e., a regime in which debate is prohibited and severely repressed). So, this position taken here is not to suggest that Austria as a country is a 'totalitarian' state or that this current study is about a regime in which debate is severely repressed. Instead, this article is concerned with the subjective experience of characters, specific social intercourses and situations in fiction as opposed to the work of fiction (i.e., Animal Farm) as a whole. Secondly, this research accepts that the inclusion of a fictional work as a whole is different from that of a part of it (Glezakos 2012). It concedes that the perspective changes if one moves from the level of a fiction book as a whole to that of the individual sentences or subjective experience of some characters therein (Longo 2015). For example, Orwell's specific words such as [a] 'All animals are equal, but some are more equal than others'; [b] 'All men are enemies. All animals are comrades'; will be used as a lens to view the social dimension of citizenship.

In particular, using fictional words of George Orwell, this article also acknowledges the socially constructed cues on citizenship and 'race' as well as different 'shades' of whiteness previously mentioned. Here, it is noteworthy that the two sentences above are situated at the core of one of the underlying themes of Animal Farm: "people's tendencies toward stratification and hierarchical grading of their fellow citizens". This particular theme in 'Animal Farm' also resonates with the stratification of the 'Self' (in-group), and the 'Other' (out-group) discussed in Bauman's ([1991] 2013) work. Indeed, these parts of "Animal Farm" conceptually illuminate the concept of racialisation even

1 It is noteworthy that a few contemporary endeavours (e.g., Lazarus 2019b; Pepper 2017) are beginning to recognise the value of fiction as tools of analysis in social science, and increasingly, this type of creative interventions seems to be gaining traction particularly, in sociology. 
though citizenship in principle advocates total equality in society. Literary works and sociology are concerned with relational processes, social relationships, social constraints and relationships, and the sociological eye can be sharpened by our engagement with literary sources (Polkinghorne 1988; Longo 2015). Arguably, fictional insight is not only considered appropriate to complement the theory of citizenship, but it is also deployed as a resourceful device in the analysis of the intersections between citizenship and 'race. Thus, the synergy between the theory of citizenship and literary text serves as a device of sociological imagination ${ }^{2}$ and analysis in this research's attempt to shed light on a colour-graded hierarchy of citizenship in an Austrian context.

\subsection{State of the Art in Literature: Austria}

The Austrian Citizenship Act does not allow dual citizenship (Nationality Act 1985). By implication, Austrian citizens from immigrant-background require visas to visit their country of origin or that of their parents. Similar to Anglophone Western nations (Burt et al. 2012; Ghafournia and Easteal 2018; Graber 2019; Hipp and Kubrin 2017; Pepper 2017; Polanco 2015), and non-Anglophone Western nations such as Italy (Colombo et al. 2009; Policek et al. 2019), Germany (Kranz 2017; Moffitt et al. 2018), 'immigrant-citizens' have inherited the negativisation bestowed historically upon those who are culturally 'Other' in Austria (Zaslove 2004; Refaie 2001; Horvath 2014; Cochrane and Nevitte 2014). As a consequence, there is widespread vilification of immigrants in the media and in political discourse that is well documented (Hipfl and Gronold 2011; Messinger 2013; Rheindorf and Ruth 2019). As Messinger (2013, p. 391) noted for example, 'xenophobic reflexes dominate the Austrian political/media discourse'. The widespread vilification of immigrants is frequently used to uncritically attack immigrants in public discourse, while operating as a 'shield' to defend racialized practices (Hipfl and Gronold 2011; Refaie 2001; Rheindorf and Ruth 2019). Therefore, the experience and narratives of the general body of 'immigrants' is indeed well articulated in the concomitant literature about Austria (Wodak and Matouschek 1993; Perchinig and Troger 1990; Supik 2014; Messinger 2013; Simon et al. 2015; Rheindorf and Ruth 2019).

Certain scholars have analysed the discourse of neo-racism and investigated anti-immigration propaganda against ethnic minorities in certain European nations including Austria (e.g., Mudde 2012; Cochrane and Nevitte 2014). These authors noted that far-right parties used high unemployment rates to increase anti-migrant attitudes. Consistent with this assumption, other scholars have examined how the welfare state and social integration policies impact negatively upon the socioeconomic position and assimilation-levels of immigrants within communities (Gang et al. 2002). Similarly, numerous other scholars (Gärtner 2017; Hofer et al. 2014; Huddleston and Tjaden 2012; Pechar 2015; Reichel and Perchinig 2015; Reichel 2012) explored migratory trends and suggested that the vilification of the migrant population in Austria has been propelled by the contemporary racist political rhetoric compressed the civic rights of immigrants. It becomes apparent that the above studies have used the terms 'foreigners' or 'immigrants', etc., to lump together a diverse range of racial minority groups. One of the limitations of this approach is that the focus on 'immigrant-citizens' as a comprehensive category has the potential to obscure hierarchies of racialized practises against particular social groups. What are the narratives of minority racial groups in Austria concerning their social citizenship?

Some scholars have differentiated between types of ethnic groups or 'immigrants'. For example, they distinguish between 'asylum seekers' and 'immigrant-citizens' in Austria (e.g., Horvath 2014; Krzyzanowski 2017; Simon et al. 2015; Supik 2014). In particular, Perchinig and Troger (1990) have specifically pointed out that individuals with an immigrant background constitute a different 'class' of citizen. Despite the fact that they are considered citizens by law, they tend to benefit less from

2 Concerning the "sociological imagination" here, while for Mills ([1959] 2000), the reconciliation is mainly between two social realities-the individual and society, for this article, alongside the above author's idea, the reconciliation is also between fictional reality and social reality. 
contested rights and privileges than the non-immigrant majority. Concurrently, 'race' serves to create a separate category called a third group. This separate category is different from 'migrants' with foreign citizenships and indigenous citizens, because its members symbolize a grey area in the citizenry arena. Therefore, as Wolfe (2017) observed, 'race' and ethnicity also serve to classify as a third group, immigrant-citizens, whom it tends to exclude from the ranks of the social citizenry. This social position of those categorized as 'a third group', reinforces the idea that citizenship rhetoric and the practical persistence of social inequality may exemplify the basic connection between 'race' and citizenship in Austria. By the same token, it also suggests that certain racial groups could fare worse than others. Arguably, the racialized narratives of citizenship merit attention, and this article views Austria as a substantively interesting site to explore the theory of citizenship alongside the fictional insights mentioned.

\section{Methodology}

\subsection{Methodological Theory}

Contexts are a resource for understanding (Goffman [1959] 1990) and based on the themes evident in the theoretical framework and literature, this research will deploy the directed approach to qualitative content analysis (DAQCA) suggested by Hsieh and Shannon (2005). The goal of a directed approach to content analysis is to explore conceptually a theoretical framework or theory (e.g., Hsieh and Shannon 2005). In a DAQCA (Hsieh and Shannon 2005), while study starts with the theory, the theoretical lenses (i.e., in this case, citizenship; citizenship and 'race' connection; fiction and social reality) can also help focus the research questions. Relatedly, codes are defined before and during data analysis and derived from theory as Hsieh and Shannon (2005) suggested. The theory (e.g., citizenship, fiction and social reality) can also guide the discussion of findings, according to a DAQCA's principle (e.g., Hsieh and Shannon 2005). In sync, aiming to explore the narratives of three different ethnic minorities in Austria, a DAQCA is most appropriate because its goal and that of this research are broadly the same: to explore or/and extend a theory (e.g., fiction and social reality).

\subsection{Methods-Participants Descriptions}

Following a DAQCA's principle (Hsieh and Shannon 2005), this research used in-depth semi-structured interviews as a means of data collection. The deployment of an in-depth semi-structured interview method, recognizes that this study involves a complex web of social phenomena (based on the themes evident in the theoretical framework and existing literature). This design was geared to explore the narratives of racial minorities, who are in Code's (1991) term, 'local-knowers'. This article conceptualizes 'local-knowers' as Austrian citizens: (1) whose parents were non-Austrians before they (parents) relocated to Austria; (2) who have lived and been schooled in Austria for more than twelve years (some of whom may or may not themselves be foreign born).

This article attempts to shed light on the narratives of three different racial and ethnic minority groups in Austria. Hence, seventy-three individuals $(n=73)$ were recruited through snowball sampling and interviewed (July 2015 to August 2016): black-Austrians $(\mathrm{n}=30)$, Turkish-Austrians ( $\mathrm{n}=23)$, and German-Austrians $(n=20)$. Out of seventy-three participants, 40 were females and 33 were males with a mean age of 28 years. While most of them $(n=50)$ were university students living in Austrian metropolitan cities, twenty were university graduates, and three had secondary school education. The selection criteria were that participants had to be Austrian citizens or nationals and also from above mentioned minority social groups (Black-Austrian, Turkish-Austrian, German-Austrian). White "German-Austrian" may be viewed as a part of the majority social group, according to a substantive aspect, the status of someone in relation to others in society viewed more broadly than when only rights entitlements are at stake. Accordingly, this article acknowledges the appropriateness of the above selection because as Bonilla-Silva and Embrick (2001, p. 62) observed, 'systematic gathering of qualitative data on Blacks as well as Whites' is crucial to capture the nuances of postmodern citizenry 
entitlements across racial/ethnic groups. Additionally, given that 'language establishes the basis of people's everyday comprehension of life' (Lazarus 2019b, p. 13), the interview method is an invaluable tool to explore the narratives of ethnic minorities in Austria.

\subsection{Data Collection}

Each interview lasted between 50 to $80 \mathrm{~min}$. A majority of the interviews were undertaken in English ( $n=53)$, whilst the others were conducted in German $(n=20)$. Because the author is an in-group member of the minority groups in Austria, i.e., a black-Austrian, this helped the interviewer to develop a high level of rapport with the interviewees-fellow members of the minority group. According to Lazarus and Okolorie's (2019, p. 18) study where a member of an organisation interviewed fellow members, "the establishment of rapport between a respondent and the interviewer, or lack thereof, is a critical aspect of the interviewer gaining the respondents' cooperation to complete a meaningful interview". It is noteworthy that although the respondents themselves chose the language selected for the interview, the preferred language could be due to the positionality of the interviewees in relation to the researcher. Most of the interviews were conducted in public spaces such as coffee shops and university cafeterias chosen by the participants. All interviews were recorded on audio-tapes and subsequently transcribed word for word into a visual form and those in German were translated into English. While involvement in the study was formalized through the signing of a consent form (Bryman 2012), ethical approval was also obtained from a university ${ }^{3}$ in the United Kingdom.

\subsection{Methods-Central Interview Question}

The primary question is listed below. Whilst the wording of the question was altered, some questions were added, depending on which aspects the researcher deemed most appropriate during the interview process.

1. How does your 'racial' or 'ethnic background' have bearing on your rights as an Austrian citizen?

\subsection{Methods-Identification of Themes, Coding and Analysis}

Interview data were transcribed verbatim and coded based on the theoretical framework discussed above. In line with DAQCA (Hsieh and Shannon 2005), data were coded and analyzed as follows. First, coding began with reading the transcripts and highlighting all text that, on first impression, appeared to represent critical aspects of citizenship and 'race' connection. In particular, the citizenship and 'race' connection served as an initial framework to highlight and identify themes from the data as Hsieh and Shannon (2005) suggested. As Hsieh and Shannon (2005) recommended, the next step in the analysis was to code all the highlighted passages using predetermined codes derived from as a conceptual device - in this case, fictional narratives. Specifically, the sensitising concepts, were derived from sentences from the Orwell's specific sentences: (a) all animals are not equal (or comrades); and (b) some animals are more equal than others. These two sentences serve as the high-level codes to highlight and recognise themes from the data. While the above synthesising concepts were the high-level codes that the author used, they were used not only to illuminate the social dimension of citizenship, but to explore the use of literary fiction in exemplifying the sociological connections between citizenship and 'race' more broadly. While this strategy may seem strange to some modern sociologists (as previously mentioned), the author, however, considered the synergy between the use of fiction as a sociological resource and DAQCA to be innovative, despite the weakness of DAQCA. Since a DAQCA is guided by a structured process (Hsieh and Shannon 2005), using a DAQCA has some inherent limitations in that the researcher has approached the data with an informed but unintended bias to some extent. Hence, the author might have been more likely to find evidence that supports 
rather than refutes the theoretical framework (discussed above). However, although a DAQCA has flaws as pointed out above, this research has valuable contributions in spite of them.

\section{Findings}

The findings below are reflective of only two related and intertwined central narratives, and in line with Hsieh and Shannon's (2005) suggestion on a DAQCA, they are presented by showing with exemplars from the data: (a) all animals are not equal (or comrades); and (b) some animals are more equal than others. While all direct quotes presented below represent widely shared narratives of the individuals interviewed, these shared narratives-the voice of the interviewees, are illustrated with indicators of proportionality as shown in Figure 1.

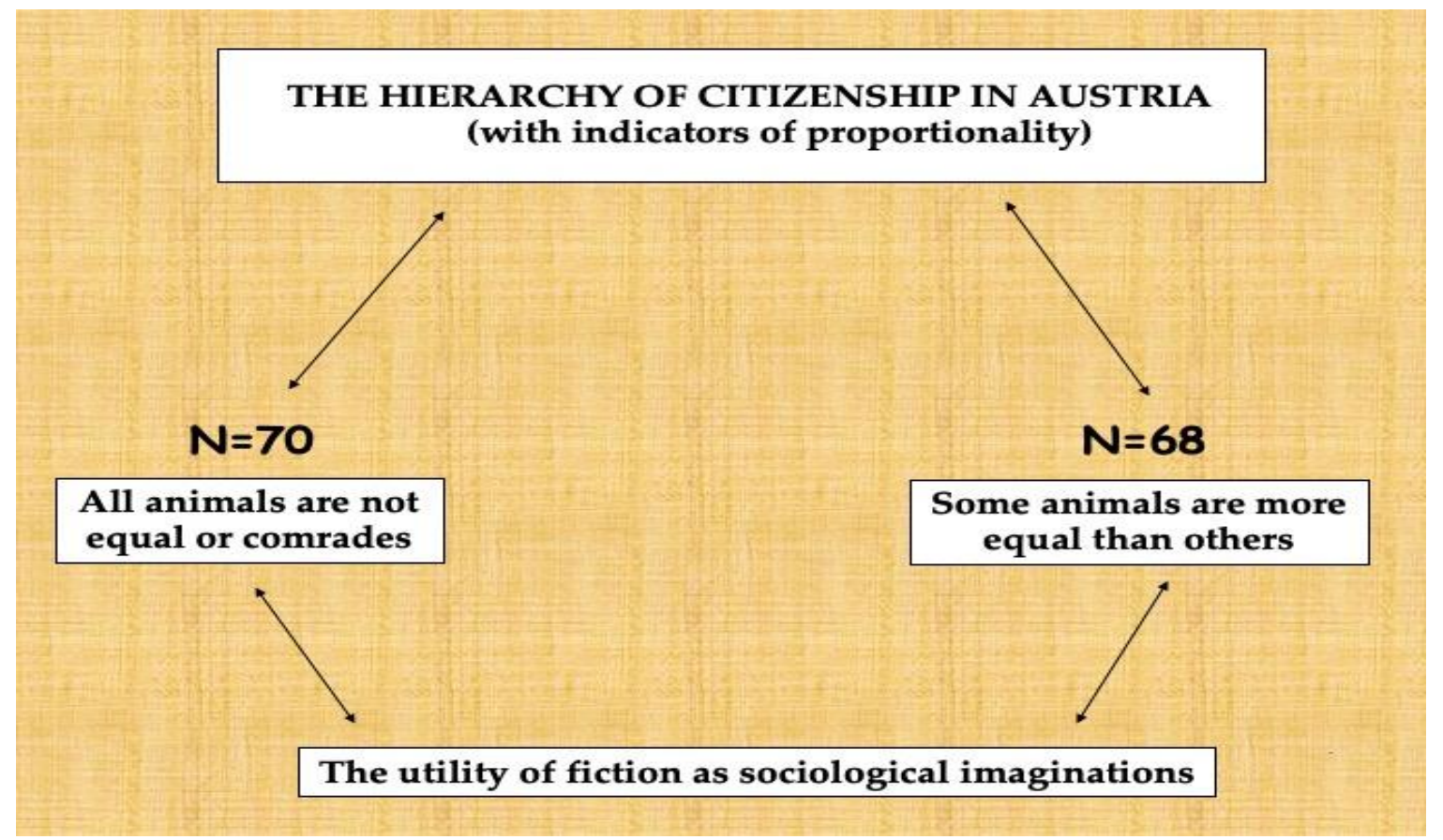

Figure 1. The Hierarchy of Citizenship in Austria with indicators of proportionality.

\subsection{All Animals are Not Equal or Comrades $(n=70)$}

In the reports from participants, black Austrians are perceived to fare worse than others on the basis of skin colour $(n=70)$. They specifically reported that the closer one resembles 'white' Austrians, the better one stands in terms of the citizenry entitlements:

'Black-is-black. Whether you have an Austrian passport or not, 'egal' [it doesn't matter]. But if you are white Austrian from here and there [other European countries], 'whiteness' opens doors for you'. [Male, Black African background]

'I think people with darker skin are most discriminated against. Black Africans ... well that sounds stupid, but the fact is people from northern Africa are classified [as] different again from other Africans ... but they are all blacks ... '. [Female, Turkish background]

'I think the ones who are easily identified [as outsiders] are the ones with the most differences to themselves. Yes, Africans, the ones who mirror [represent] the biggest difference'. [Female, German background]

'For example, I have a friend from [Kenya] ... a nurse. She says that sometimes in the hospital patients shout at her: "Don't touch me! Don't touch me!" She only wants to prepare 
them to get an injection ... or something like that ... but they tell her: "Don't touch me!" Because she is black. If she is white from God-knows-where, they wouldn't see the colour and they wouldn't say: "Don't touch me!" ... '. [Female, Black African background]

However, it is noteworthy that two respondents $(n=3)$ contradictorily mentioned, 'Roma' group members fare worse than others, despite this group not being included in the sample: 'I think, 'Roma'. Because I hear a lot of people complaining about "Roma" people ... yeah, they don't like working, they just like begging ...'

\subsection{Some Animals Are More Equal Than Others $(n=68)$}

Similarly, it was also reported by each group interviewed that lighter-skinned individuals are 'more equal' than darker-skinned ones as regards to their social dimension of citizenship:

'... my opinion is that [some] people suffer less discrimination because they are white. [Followed by] Turkish people and Arabs and other immigrant background [who] also have an advantage over black people. Even if they've just an ordinary visa in their hands and are newcomers. Because of skin colour ... they are better off than black Austrians'. [Male, Black African background]

'I just remember one time while shopping someone [openly] addressed me as 'Piefke' ... and I said to myself, "Oh now it happens even to me!" ...But I can't compare it to what other immigrants suffer ... for example, my husband [is] from Nigerian origin'. [Female, German background]

'Passport' will not help you with anything. You have the citizenship and still have no respect from people ... What does that mean? It means that your 'passport' is divided into two, you know ... If your passport is halved that also means your ration as an Austrian is halved... The epic thing is that a brother with a passport, university degree, and all that ... is lower than a Kosovo man or a Turkish man, or some 'halal meat' from Arab ... that may only have training in how to slaughter ram or cut onions and make kebab .... I don't know how to describe it ... but the real whites are like kings, the other fake whites are their royal servants and ... blacks are common slaves'. [Male, Black African background]

'All whites think they are better than people from my homeland [Turkey]. Blacks unfortunately I must say are at the floor [bottom]. It's true .... Everyone is ranked [laughed at] like in the military'. [Male, Turkish background]

\section{Discussion}

In order to enhance the voice of the interviewed and their widely shared stories, the use of fiction as an analytic device and the product of such data analysis are illustrated with a box-and-arrow diagram above. This diagram above (i.e., Figure 1), guides the bulk of the discussion of findings. The discussion focuses sequentially on two related and intertwined strands of narratives: (a) "all animals are not equal or comrades" ( $n=70)$; (b) "some animals are more equal than others" $(n=68)$. These themes are related because on the one hand, the official rhetoric of citizenship and the continuation of racialized interactional-based practices/experiences are connected (Wolfe 2017). On the other hand, citizenship itself has historically relied upon racial and cultural sameness to deliver its ideal principles of equality and tolerance in practice (Dahlstedt et al. 2017). Social citizenship, as Glenn (2009) reminded us, grants individuals the means to translate formal rights into substantive rights-the capacity to participate in social life. By implication, 'some animals are more equal than others' because racial minorities (largely perceived as different) are generally viewed as a subordinate category in relation to the indigenous majority. This dichotomy between the indigenous majority and the subordinate 
category could also be understood in the light of Bauman's ([1991] 2013) conceptualization of the 'Self' and the 'Other'.

The ability to turn formal rights into substantive rights generally depends on group membership: the 'Self' and the 'Other' - simply put in racial terms. The 'Self' and the 'Other' are mutually dependent. As Bauman ([1991] 2013, p. 14) observed:

In dichotomies crucial for the practice and the vision of social order the differentiating power hides as a rule behind one of the members of the opposition. Both sides depend on each other, but this dependence is not symmetrical. The second side depends on the first for its contrived and enforced isolation. The first depends on the second for its self-assertion.

However, going beyond this seemingly binary conceptualisation of the 'Self' and the 'Other', this scholarly endeavour deploys the application of a more refined conceptualisation of the narratives of minority groups, which could not fit into the dual lens. Beyond the binary conceptualisation (the Self and the Other), interview data (i.e., 'All animals are not equal (or comrades)') indicated that the darker skinned members of the community are perceived to experience the most compressed form of social citizenship, privileges and entitlements. Specifically, they articulated that racial groups who 'represent the biggest difference' suffer more than other minority groups that resemble a 'white' majority. This suggests that relational processes perpetuate perceived inferiority and superiority through racialized practices of citizenship—against certain racial minority groups (e.g., black-Austrians) more than others (e.g., Turkish-Austrians). The idea is also reflective of the difference between Anderson's (2013) and Marshall and Bottomore's (1992) positions on the substantive aspect of citizenship. Unlike Marshall and Bottomore's concept, more recent scholarship has pointed out that an individuals' ability to turn formal rights into substantive rights intersects not only with class, but also with 'race' (Anderson 2013; Graber 2019; Ladson-Billings 2010). However, it was also mentioned $(n=3)$ that "Roma", who may be seen as 'whites, could fare worse than blacks. Whilst this acknowledges different shades of whiteness and supports the notion that 'some animals are more equal than others', it is challenging to ascertain whether those "Roma people" popularly seen as "beggars" are settlers-i.e., Austrian citizens or travellers. Nonetheless, future studies would benefit from looking closely at "Roma people": looking at this group was beyond the scope of this study.

This does not undermine the fact that interview data $(n=70)$ supports that idea that 'all animals are not equal', because those that signify the greatest otherness consequently fare worse than other minority racial groups-possibly in terms of employment opportunities, and social mobility. The key point here is that, people who look different from the majority are broadly worse off in terms of class positions (Philips and Platt 2016; Platt 2002; Song 2014). Given that class and 'race' are two sides of the same coin, they mutually construct each other. As Song (2014) noted for example, the efficacy of 'race' and class could also extend to future generations, which means that the inequality of 'animals' has enduring real life consequences. It not only reinforces Glenn's (2009) idea that social citizenship helps to equip individuals with the ability to translate formal rights into the realm of substantive rights; it also has intergenerational consequences. In other words, to be perceived as the most inferior group of citizens has the potential of having a disproportionate negative impact upon a group in relation to other minority groups. Therefore, there is a huge deviation between citizenship in principle and in practice (e.g., Aburabia 2017; Kranz 2017; Lavee and Benjamin 2017; Lazarus et al. 2017). In this case, it is biased against the powerless along the axis of skin colour, and physiological differences are implicated in inequalities in 'all the animal kingdom'.

Also, regarding the perpetuation and reproduction of 'otherness', much of reality is complex. Unlike Orwell's words, "All men are enemies. All animals are comrades", not all racial minority groups are necessarily "comrades". By the same token, not all indigenous Austrians are 'enemies' of those citizens from immigrant backgrounds. To illustrate, some black respondents referred to other 
minority groups, for example, Muslims ${ }^{4}$, who have a lighter skin colour as "halal meat", which is also an offensive and dehumanising name in any context. Whilst it reinforces the idea that not all minority groups are "comrades", other ethnic/racial minority groups in Austria are also involved the perpetuation and reproduction of 'otherness', which is evident in one of the participant's reports:

"... there was a black woman, a cleaner in their company. The cooks, Turkish, were harassing her till she left work after a month. I tried to help her but because the 'cooks' were more in number and so had more 'power', she decided to resign" [Female, Turkish background]

To dismiss a discussion on how 'the second member is but the opposite (degraded, suppressed) side of the first' (Bauman [1991] 2013, p. 14), is to become vulnerable to omitting crucial factors that are necessary to understand the hierarchy of citizenship in Austria. Here, 'white advantage is the mirror of, and made possible by, minority disadvantage' (Philips and Platt 2016, p. 242). The degrading and suppression of second members' rights underscores that the first members depend on the second for their self-assertion-which is, in this case, based on skin colour. Sociological inquiries and literary works, when they 'hold hands', are useful tools in the exemplification of human relations and experiences (Cappetti 1993, p. 32; see also Longo 2015, p. 61). The bottom line here is that physiological differences lie at the root of the inequality stressed in Orwell's specific words, 'All animals are equal, but some are more equal than others'. By the same token, physiological differences may have influenced the widely shared narratives of the three minority racial groups reported in this study. The latter also contributes to the emerging literature in Austria (Gärtner 2017; Hipfl and Gronold 2011; Hofer et al. 2014; Huddleston and Tjaden 2012; Krzyzanowski 2017; Pechar 2015; Reichel and Perchinig 2015; Reichel 2012; Supik 2014; Rheindorf and Ruth 2019) on the intergenerational citizenry tensions between the 'Self' (indigenous-Austrians) and the 'Other' (Austrians from immigrant backgrounds). Even if locating the source of compressed social rights and entitlements exclusively within the construct of 'race' may be simplistic (Shutes 2016), the current endeavour suggests that 'race' or 'immigrant background' (popularly used in continental European literature) is a very important factor that exposes a colour-graded hierarchy of citizenship entitlements in Austria.

'Some animals are more equal than others' is another central theme, which represents widely shared stories of the interviewees $(n=68)$. Indeed, it is the second main strand of narratives emerging from the data analysis, as shown in Figure 1 with indicators of proportionality. Corresponding to the findings of some scholars (Krzyzanowski 2017; Perchinig and Troger 1990; Supik 2014), people from 'immigrant backgrounds' have different experiences of citizenship in relation to 'the Self', and 'just like in the military', they are ranked in racial terms. Specifically, interview data has helped shed light on the ways in which lived experience and narratives vary across a diverse cross-section of ethnic and social groups in Austria. Individuals' social citizenship and entitlements to civic rights are hierarchically ranked according to their skin colour. Broadly speaking and as per the findings mentioned above, at the current historical moment in Austria, black-Austrians, Turkish-Austrians, and German immigrant-citizens (in descending order of significance) experience unequal civic rights and social citizenship. While all minority groups are 'clumped together' as one (equal), in terms of social and civic rights, some minority racial groups are more equal than others. Particularly, data suggests that while a German-Austrian is socially perceived as being better off than a Turkish-Austrian, a black-Austrian is perceived as faring worse than a Turkish-Austrian. The bottom line is that 'some

4 Concerning Muslims, 'in Austria, the Federal Constitution provides a guarantee of freedom of religion in general and also the right to manifest one's religion in private and in public as long as this does not conflict with public order and customs' (Permoser and Rosenberger 2016, p. 149). However, the law only affords a limited scope for protecting the privileges and rights of oppressed minority groups, not the least because relational processes generally situate minority religious groups as inferior and position the majority as superior with regards to their citizenry entitlements.

5 Halal meat is the meat which adheres to Islamic law and involves the slaughtering of animals or poultry through a cut to the jugular vein, carotid artery, and windpipe. 
animals are more equal than others' in the 'Austrian kingdom' and that 'race' and racism matter, as Ladson-Billings (2010) has noted. They have real-life social penalties.

'All animals are equal, but some are more equal than others', and although the sentence in Orwell's book (1955) is an allegorical work of fiction, it helps to illustrate the hypocrisy of social relations that appear to proclaim equality among citizens but in that reality, privileges particular social groups above others. It is noteworthy that the above sentence is specifically located at the core of one of the underlying themes of Animal Farm: "people's tendencies toward stratification and hierarchical grading of their fellow citizens". One of the implications is that the homogenization of 'immigrant-citizens' as a group is vulnerable to obscuring the differential layers of immigrants' lived experiences and concomitantly, their narratives. This also acknowledges different 'shades' of whiteness, because some people from Germany are white as are some people from Turkey, but German-Austrians are generally perceived to be less 'foreign' than Turkish-Austrians, due to perceived different shades of whiteness in relational terms. By the same token, whilst most Germans are as white as most Austrians, some Austrian see Austrian-Germans as 'Piefken'. Piefke is a degrading nickname for Germans in Austria meaning 'pompous idiot'; hence discrimination occurs despite both groups being 'white'.

The underlying assumption is that there are varying degrees of 'equality' across a diverse spectrum of minority social groups within the overarching theme of Austrian citizenship. Although the emancipatory character of citizenship is universalizable (Domingues 2017), its particularized feature in Austria in terms of entitlements is interesting. According to a female participant from a Turkish background, black-Austrians, ' ... even second or third generation, no matter their social status suffer more ... [than other minority groups]'. This invokes the African proverb that states that although all trees have their roots in the same ground, the sun 'favours' taller trees over the shorter ones. This proverb reinforces the idea that while some migrants are citizens by law, they are still constructed as second-class citizens in public discourse-as well as in media/political discourse (Brubaker 1992; Gilroy 1987). This echoes Orwell's words that 'liberty is worth more than just ribbons'. 'Ribbons' can here be conceptualized as citizenship in principle and its legal symbols (e.g., passports), whereas its substantive aspects are critical sources of social advantage and disadvantage that encompass the everyday reality of citizenship. The law not only has a limited scope for protecting the privileges and rights of oppressed minority groups; it also protects the rights and privileges of individuals disproportionately, namely according to their perceived 'race'. Hence, 'liberty is worth more than just ribbons'. The function of literature is 'to illuminate the material that the sociologists study' (Farrell 1954:180; see also Longo 2015, p. 60). Thus, the synergy between the concept of citizenship and literary text as a device of sociological imagination offers an additional layer of explanation of a colour-graded hierarchy of citizenship. So, since citizenship is a precondition for possessing certain rights that non-citizens are not granted, I argue here that 'citizenship' should not only be judged by whom it, in principle, excludes (i.e., non-citizens), but also by how it treats different groups of the included (i.e., citizens) on the basis of their 'race'.

How a person experiences and perceives her/his everyday life is reminiscent of the Austrian playground game, which reflects civilians' antagonistic attitudes towards dark skin colour. It transpires that while most Austrians (both minority and majority groups) are less concerned about the issues surrounding them in the political domain of rights, they become more preoccupied with notions of 'blackness' in the civic and social sphere of citizenship. For instance, within the overarching category of minority racial groups, a black-Austrian might be excluded from certain public spaces, which devalues their citizenship, whereas a Turkish-Austrian would not experience this form of discrimination: '[S]ometimes I go to a club ... they tell me, 'No! You can't enter, it's a private party' ... and that's it! ... It [blackness] affects my social life, you know', possibly like the metaphorical black man in the Austrian playground game. It is too simplistic to view the above as just an example of racial discrimination that is often experienced by minority groups in Europe irrespective of their citizenship status (Reiner 2016). Austria usually does not allow dual citizenship and individuals are mainly either Austrians or non-Austrians, regardless of their ethnic/racial background (e.g., Reichel and Perchinig 2015). This has a profound implication for citizenship. Belonging to a society as a citizen differs 
according to the particularities of individuals (e.g., Glenn 2009), because a public space, as illustrated above, has been re-defined as 'a private and restricted space'. This fluctuating meaning of public spaces based on the physical characteristics of a person goes against the right to equality in 'public spaces'—or civil rights. Thus, it resonates with the idea that 'a man in an unwanted place is a weed' (Lazarus 2019c, p. 1), and a weed by definition refers to 'a wild plant growing where it is not wanted and in competition with cultivated plants'. In this respect, anyone perceived to be 'a weed' on the basis of his or her physical characteristics is excluded from specific social spaces (as exemplified by the direct quote above, which represents a widely shared experience of the interviewees). Beyond abstraction, it is reasonable therefore to argue that 'race' restored the social inequality that citizenship has theoretically aimed to undo. This article's position supports Wolfe's (2017) analysis of the connections between 'race' and citizenship.

Furthermore, some individuals have more access to civic rights and social citizenship than other members of their ethnic group, irrespective of the general disadvantages of that group. On the one hand, this echoes Marshall and Bottomore's (1992) theory that status and entitlements, the 'right to have rights', can increase according to social class. According to a female participant from a German background, black-Austrians are worst off in terms of entitlements, unless 'he/she is David Alaba and plays football ... then it's different....' This also suggests that, perhaps, the status conferred on certain black members of Austrian society may nullify the impact of negative racialized practices commonly levelled against their ethnic group as a whole. On the other hand, it emphasizes Dahlstedt and Vesterberg's (2017) idea that citizenship is a precondition for possessing certain rights and therefore is an on-going process subject to factors such as social mobility (e.g., the trajectory from ordinary middle-class citizen to sports celebrity). While David Alaba was born to a Nigerian father and a Filipino mother (immigrant parents), he is the youngest Austrian player to play for Austria's senior national team (as well as an internationally acclaimed football club, Bayern Munich).

As a consequence, despite Alaba the footballer being a member of a black Austrian group, he has the elevated social status available to celebrities. He not only enjoys a higher level of privileges than most members of his group, but he also enjoys a higher level of privileges more than most members of the overall Austrian society (even the white middle class citizens). Alaba the footballer is a very influential member of the Austrian social/political community, according to general media discourse (e.g., BBC 2016). Arguably, citizenship is never static. The parameters of citizenship are constantly shifting and involve a set of complex power relations. This position challenges the applicability of the Austrian tag game to every black person in Austrians, because no one would apparently be 'scared of a black man', if he is Alaba the footballer, 'Nobody!' And whenever he is seen by fans, they would not 'run away!', but possibly try to shake his hand and get his autograph. Additionally, the above insights reinforce the assumption that economic disadvantage varies between members of the same racial group, depending on individual resources for social mobility or on becoming a celebrity statesman like Alaba the footballer. By the same token, the above insights reinforce the notion that one's status as a citizen is not inherent or static but continually being constructed and negotiated (e.g., Dahlstedt et al. 2017; Dahlstedt and Vesterberg 2017).

\section{Conclusions}

This article is the first study to use fictional tools as a sociological resource in exemplifying the deviation between citizenship in principle and practice in an Austrian context. It has explored the connections between citizenship and 'race'/ethnicity. By doing so, it has attempted to answer the question: What are the narratives of racial minorities in Austria concerning their citizenship entitlements? In appreciating the compatibilities between literary works and qualitative data, the article has argued that while 'all animals are not equal, some are more equal than others', and that skin colour is a specific aspect of these graded levels of inequalities. In particular, it has proposed that in Austria, individuals' experiences of citizenship are hierarchically ranked according to an individual's racial features (particularly skin colour). It has been suggested that, at the current historical moment in 
Austria, Austrian-Germans, Austrian-Turks, and black-Austrians, (in ascending order of significance) broadly experience hierarchical levels of entitlements to certain rights, whereas they (as a group) are largely seen socially as second-class citizens within the public discourse.

That said, this study would have benefited from the inclusion of a wider spectrum of ethnic groups. Another key limitation of this current study is its selective sample of respondents. This selectiveness is derived from the fact that a majority of the participants preferred to be interviewed in English. This preferred language could be due to the positionality of most interviewees (fifty university students and twenty university graduates) in relation to the interviewers. The fundamental point here is that this type of sample, may have affected the type of response generated from the study. In fact, it may also have had unintended consequences for the overall study. To this end, further research with a greater number of participants and a more diverse set of participants would be required to fully substantiate its claims. By the same token, further research could also extend this study beyond its present scope by involving participants from two or more European nations. This research path, based on a systematic gathering of qualitative data, could place future researchers in a better position to capture the nuances of postmodern citizenry entitlements across European nations.

Additionally, in critiquing the evidence, caution should be applied in the interpretation of this study's findings, as previously mentioned. Using the theory of citizenship according to the doctrines of a DAQCA and coding the data innovatively based on literary text have some inherent shortcomings: the researcher has approached the data not only with an informed but also with an unintended bias to some degree. Thus, the author might have been more likely to find evidence that supports rather than refutes the theory (e.g., citizenship and 'race' connection). Also, an overemphasis on the connections between Orwell's words and social citizenship may have inhibited the present researcher's efforts in acknowledging other contextual situatedness of the phenomenon to some extent.

Despite these limitations, this article contributes to the emerging debate in Austria on the fact that immigrant-citizens are largely perceived as second-class citizens (Messinger 2013; Pechar 2015; Reichel and Perchinig 2015; Supik 2014). Based on the evidence from the field work presented in this article, the deviation between citizenship in principle and in practice can be situated within the constructs of 'race'. This exemplifies the basic connection between 'race' and citizenship in Austria, because the former appears to restore the social inequality that the latter has theoretically aimed to dismantle. Additionally, social fiction was intertwined with social reality in this current endeavour, and the connection between the two is enlightening. The use of literature as a critical device offered additional layers of explanation. The manifestation of a colour-graded hierarchy of citizenship in Austria, for example, is reflective of the one of the underlying themes of Animal Farm: "individuals' tendencies toward stratification and hierarchical grading of their fellow citizens". Thus, the central argument comes back to its beginning: all 'animals' may be equal in principle, whereas, in practice, their 'race' serves as critical sources of social (dis)advantage in the 'animal kingdom'. Thus, since citizenship is a precondition for possessing certain rights that non-citizens are not granted, I argue that citizenship cannot only be judged by whom it, in theory, excludes (i.e., non-citizens), but also by how it treats the included (i.e., citizens) on the basis of their 'race', as discussed above.

Funding: This research received no external funding.

Acknowledgments: In November 2015, I presented this research at the Graduate Centre, CUNY, New York, and I thank the organizers and participants of the conference (e.g., members of Alfred Deakin Institute for Citizenship and Globalisation, Australia). I am grateful to Kerstin Aglassinger-Nyalusi for her assistance during the early phase of the interview process in Austria. I thank Lucinda Platt, Laura Christie and José Maurício Domingues for providing useful feedback on the preliminary version of this research. I also thank the academic editor of this article/journal and the anonymous reviewers for their thoughtful recommendations.

Conflicts of Interest: The author declares no conflict of interest. 


\section{References}

Aburabia, Rawia. 2017. Trapped between national boundaries and patriarchal structures: Palestinian Bedouin women and polygamous marriage in Israel. Journal of Comparative Family Studies 48: 339-49. [CrossRef]

Agozino, Biko. 2018. Black Women and the Criminal Justice System: Towards the Decolonisation of Victimisation. London: Routledge.

Akrivopoulou, Christina M. 2013. Citizen and Citizenship in the Era of Globalization: Theories and Aspects of the Classic and Modern Citoyen. In Digital Democracy and the Impact of Technology on Governance and Politics: New Globalized Practices: New Globalized Practices. Edited by Christina Akrivopoulou and Nicolaos Garipidis. Hershey: IGI Global.

Alexander, Michelle. 2012. The New Jim Crow: Mass Incarceration in the Age of Colorblindness. New York: The New Press.

Anderson, Bridget. 2013. Us and Them?: The Dangerous Politics of Immigration Control. Oxford: OUP Oxford.

Banton, Michael. 1998. Racial Theories. Cambridge: Cambridge University Press.

Bauman, Zygmunt. 2013. Modernity and Ambivalence. Cambridge: Polity Press. First published 1991.

BBC. 2016. 'David Alaba'. Available online: http://www.bbc.co.uk/sport/football/35842558 (accessed on 24 April 2017).

Bellamy, Richard. 2008. Citizenship: A Very Short Introduction. Oxford: Oxford University Press.

Bonilla-Silva, Eduardo, and David G. Embrick. 2001. Are Blacks Color Blind Too?: An Interview-Based Analysis of Black Detroiters' Racial Views. Race and Society 4: 47-67. [CrossRef]

Brubaker, Rogers. 1992. Citizenship and Nationhood in France and Germany. Cambridge: Harvard University Press. Bryman, Alan. 2012. Social Research Methods. Oxford: Oxford University Press.

Burt, Callie Harbin, Simons Roland L, and Gibbons Frederick X. 2012. Racial Discrimination, Ethnic-Racial Socialization, and Crime: A Micro-sociological Model of Risk and Resilience. American Sociological Review 77: 648-77. [CrossRef] [PubMed]

Byerman, K. 2019. Talking Back: Phillis Wheatley, Race and Religion. Religions 10: 401. [CrossRef]

Cappetti, C. 1993. Writing Chicago: Modernism, Ethnography, and the Novel. New York: Columbia University Press. Carr, David. 2008. 1. Narrative Explanation and Its Malcontents. History and Theory 47: 19-30. [CrossRef]

Cochrane, Christopher, and Neil Nevitte. 2014. Scapegoating: Unemployment, Far-right Parties and Anti-immigrant Sentiment. Comparative European Politics 12: 1-32. [CrossRef]

Code, Lorraine. 1991. What Can She Know?: Feminist Theory and the Construction of Knowledge. New York: Cornell University Press.

Colombo, Enzo, and Paola Rebughini. 2016. Intersectionality and Beyond. Rassegna Italiana di Sociologia 57: 439-60.

Colombo, Enzo, Leonini Luisa, and Rebughini Paola. 2009. Different but Not Stranger: Everyday Collective Identifications Among Adolescent Children of Immigrants in Italy. Journal of Ethnic and Migration Studies 35: 37-59. [CrossRef]

Dahlstedt, Magnus, and Vicktor Vesterberg. 2017. Citizens in the Making: The Inclusion of Racialized Subjects in Labour Market Projects in Sweden. Scandinavian Political Studies 40: 228-46. [CrossRef]

Dahlstedt, Magnus, Runqvist Mikael, and Vesterberg Vicktor. 2017. Citizenship—Rights, Obligations and Changing Citizenship Deals. Available online: https://www.academia.edu/9148828/Citizenship_Rights_ Obligations_and_Changing_Citizenship_Ideals (accessed on 18 November 2017).

Domingues, Jose Mauricio. 2017. From Citizenship to Social Liberalism or Beyond? Some Theoretical and Historical Landmarks. Citizenship Studies 21: 167-81. [CrossRef]

Farrell, James T. 1954. Some Observation on Literature and Sociology. In Reflections at Fifty and other Essays. Edited by James T. Farrell. New York: Vanguard Press, pp. 142-55.

Favell, Adrian. 1998. A Politics that is Shared, Bounded, and Rooted? Rediscovering Civic Political Culture in Western Europe. Theory and Society 27: 209-36. [CrossRef]

Ferrajoli, Luigi. 2001. Fundamental Rights. International Journal for the Semiotics of Law 14: 1-33. [CrossRef]

Fogiel-Bijaoui, Sylvie. 2016. The Cosmopolitan Future: A Feminist Approach. Laws 5: 34. [CrossRef]

Forsyth, Craig J., Howat Holly, Pei Lai K, Forsyth York A, Asmus Gary, and Stokes Billy R. 2013. Examining the infractions causing higher rates of suspensions and expulsions: Racial and ethnic considerations. Laws 2: 20-32. [CrossRef] 
Gang, Ira N., Francisco Rivera-Batiz, and Myeong-Su Yun. 2002. Economic Strain, Ethnic Concentration and Attitudes towards Foreigners in the European Union. Available online: http://www.econstor.eu/bitstream/ 10419/21350/1/dp578.pdf (accessed on 26 March 2014).

Gärtner, Reinhold. 2017. The FPÖ, foreigners, and Racism in the Haider Era. In The Haider Phenomenon in Austria. Edited by Ruth Wodak and Anton Pelinka. New Brunswick: Transaction Publishers, pp. 17-32.

Ghafournia, Nafiseh, and Patricia Easteal. 2018. Are Immigrant Women Visible in Australian Domestic Violence Reports that Potentially Influence Policy? Laws 7: 32. [CrossRef]

Gibson, John. 2007. Fiction and the Weave of Life. Oxford: Oxford University Press.

Gilroy, Paul. 1987. There Ain't No Black in the Union Jack: The Cultural Politics of Race and Nation. London: Routledge.

Glenn, Evelyn Nakano. 2009. Unequal Freedom: How Race and Gender Shaped American Citizenship and Labor. London: Harvard University Press.

Glezakos, Stavroula. 2012. Truth and Reference in Fiction. In The Routledge Companion to Philosophy of Language. Edited by Gillian Russel and Delia Graff Fara. London: Routledge, pp. 177-85.

Goffman, Erving. 1990. The Presentation of Self in Everyday Life. New York: Doubleday. First published 1959.

Gonzales Rose, Jasmine B. 2017. Toward a Critical Race Theory of Evidence. Minnesota Law Review 101: $2016-29$.

Graber, Jennifer. 2019. Natives Need Prison: The Sanctification of Racialized Incarceration. Religions 10: 87. [CrossRef]

Hazard, Anthony Q. 2011. A Racialized Deconstruction? Ashley Montagu and the 1950 UNESCO statement on race. Transforming Anthropology 19: 174-86. [CrossRef]

Hipfl, Brigitte, and Daniela Gronold. 2011. Asylum Seekers as Austria's Other: The Re-Emergence of Austria's Colonial Past in a State-of-exception. Social Identities 17: 27-40. [CrossRef]

Hipp, John R., and Charis E. Kubrin. 2017. From bad to worse: How changing inequality in nearby areas impacts local crime. RSF: The Russell Sage Foundation Journal of the Social Sciences 3: 129-51. [CrossRef]

Hofer, Helmut, Titelbach Gerlinde, and Winter-Ebmer Rudolf. 2014. Wage Discrimination against Immigrants in Austria? (No. 1406). Working Paper. Linz: Department of Economics, Johannes Kepler University of Linz.

Horvath, Kenneth. 2014. Policing the Borders of the 'Centaur State': Deportation, Detention, And Neoliberal Transformation Processes-The Case of Austria. Social Inclusion 2: 113-23. [CrossRef]

Hsieh, Hsiu-Fang, and Sarah E. Shannon. 2005. Three Approaches to Qualitative Content Analysis. Qualitative Health Research 15: 1277-88. [CrossRef] [PubMed]

Huddleston, Thomas, and Jasper D. Tjaden. 2012. Immigrant Citizens Survey. How Immigrants Experience Integration in 15 European Cities. Brussels: Joint publication of the King Baudouin Foundation and the Migration Policy Group.

Ibrahim, Suleman. 2015. A Binary Model of Broken Home: Parental Death-Divorce Hypothesis of Male Juvenile Delinquency in Nigeria and Ghana. In Contemporary Perspectives in Family Research. Edited by Sheila Royo Maxwell and Sampson Lee Blair. New York: Emerald Group Publishing Limited, vol. 9, pp. 311-40.

Kranz, Dani. 2017. Changing Measures of the Quantum of Sufficient Germanness: Access to German Citizenship of Children of German/Non-German Parentage, and Children Eligible under Jus Soli Provisions. Journal of Comparative Family Studies 48: 367-79. [CrossRef]

Krzyzanowski, Michal. 2017. The Politics of Exclusion: Debating Migration in Austria. New York: Routledge.

Ladson-Billings, Gloria. 2010. Just What is Critical Race Theory and What's It Doing in a Nice Field Like Education? International Journal of Qualitative Studies in Education 11: 7-24. [CrossRef]

Lavee, Einat, and Orly Benjamin. 2017. Between Social Rights and Human Rights: Israeli Mothers' Right to be Protected from Poverty and Prostitution. Journal of Comparative Family Studies 48: 315-26. [CrossRef]

Lazarus, Suleman. 2019a. Just married: the synergy between feminist criminology and the Tripartite Cybercrime Framework. International Social Science Journal, 1-19. [CrossRef]

Lazarus, Suleman. 2019b. Where Is the Money? The Intersectionality of the Spirit World and the Acquisition of Wealth. Religions 10: 146. [CrossRef]

Lazarus, Suleman. 2019c. Betrayals in Academia and a Black Demon from Ephesus. Wisdom in Education 9: 3.

Lazarus, Suleman, and Geoffrey U. Okolorie. 2019. The bifurcation of the Nigerian cybercriminals: Narratives of the Economic and Financial Crimes Commission (EFCC) agents. Telematics and Informatics 40: 14-26. [CrossRef]

Lazarus, Suleman I., Michael Rush, Edward T. Dibiana, and Claire P. Monks. 2017. Gendered penalties of divorce on remarriage in Nigeria: A qualitative study. Journal of Comparative Family Studies 48: 351-66. [CrossRef] 
Longo, Mariano. 2015. Fiction and Social Reality: Literature and Narrative as Sociological Resources. Surrey: Ashgate Publishing Limited.

Malkki, Liisa H. 1997. Purity and Exile. Chicago: University of Chicago Press.

Marshall, Thomas Humphrey. 1950. Citizenship and Social Class and Other Essays. Cambridge: Cambridge University Press.

Marshall, Thomas Humphrey, and Thomas Bottomore. 1992. Citizenship and Social Class. London: Pluto Press.

Messinger, Irene. 2013. There is something about marrying ... The case of human rights vs. migration regimes using the example of Austria. Laws 2: 376-91. [CrossRef]

Mills, Charles Wright. 2000. The Sociological Imagination. Oxford: Oxford University Press. First published 1959.

Moffitt, Ursula, Linda P. Juang, and Moin Syed. 2018. “We don't do that in Germany!” A critical race theory examination of Turkish heritage young adults' school experiences. Ethnicities, 1-28. [CrossRef]

Mudde, Cas. 2012. The Relationship between Immigration and Nativism in Europe and North America. Washington, DC: 10th Anniversary MPI Migration Policy Institute, pp. 1-42.

Nationality Act. 1985. Federal Law Concerning Austrian Nationality. Available online: https:/www.refworld.org/ docid/5c863d394.html (accessed on 22 February 2017).

Orwell, Gorge. 1955. Animal Farm. London: Penguin.

Park, Robert E., and Ernest W. Burgess. 1921. Introduction to the Science of Sociology. Chicago: University of Chicago Press.

Pechar, Hans. 2015. Austria: From Legacy to Reform. Education in the European Union: Pre-2003 Member States 1: 21.

Pepper, Andrew. 2017. Race, violence and neoliberalism: crime fiction in the era of Ferguson and Black Lives Matter. Textual Practice, 1-20. [CrossRef]

Perchinig, Bernhard, and Tobias Troger. 1990. Migrationshintergrund als Differenzkategorie. Vom Notwendigen Konfliket Zwischen Theorie und Empirie in der Migrationsforschung. In Zukunft. Werte. Europa. Die Europäische Wertestudie 1990. Edited by Polak Regina. Wien: Böhlau.

Permoser, Julia Mourão, and Sieglinde Rosenberger. 2016. Religious citizenship as a substitute for immigrant integration? The governance of diversity in Austria. In Illiberal Liberal States. London: Routledge, pp. 149-64.

Philips, Coretta, and Lucinda Platt. 2016. 'Race' and Ethnicity. In 2016 Social Advantage and Disadvantage. Edited by Hartley Dean and Lucinda Platt. Oxford: Oxford University Press.

Platt, Lucinda. 2002. Parallel Lives? Poverty among Ethnic Minority Groups in Britain. (No. 107). London: Child Poverty Action Group.

Platt, Lucinda. 2016. Class, Capital and Social Mobility. In 2016 Social Advantage and Disadvantage. Edited by Hartley Dean and Lucinda Platt. Oxford: Oxford University Press.

Polanco, Mieka Brand. 2015. Punishment and the State: Imprisonment, Transgressions, Scapegoats, and the Contributions of Anthropology: An Introduction. PoLAR: Political and Legal Anthropology Review 38: 200-3.

Policek, Nicoletta, Ravagnani Luisa, and Romano Carlo. 2019. Victimization of young foreigners in Italy. European Journal of Criminology, 1-9. [CrossRef]

Polkinghorne, Donald. 1988. Narrative Knowing and the Human Sciences. Albany: State University of New York Press.

Redfield, Robert. 1962. Social Science among the Humanities. In Human Nature and the Study of Society: The Papers of Robert Redfield. Edited by Margaret Park Redfield. Chicago: University of Chicago Press, Vol. I, pp. 43-57.

Refaie, Elisabeth. 2001. Metaphors We Discriminate By: Naturalized Themes in Austrian Newspaper Articles About Asylum Seekers. Journal of Sociolinguistics 5: 352-71. [CrossRef]

Reichel, David. 2012. Regulating Political Incorporation of Immigrants-Naturalisation Rates in Europe. Vienna: International Centre for Migration Policy Development.

Reichel, David, and Bernhard Perchinig. 2015. Reflections on the value of citizenship-explaining naturalisation practices/Der Wert der Staatsbürgerschaft: Zur empirischen Erklärung von Einbürgerungspraxen. Österreichische Zeitschrift für Politikwissenschaft 44: 32-45. [CrossRef]

Reiner, Robert. 2016. Crime, the Mystery of the Common-Sense Concept. London: Polity.

Rheindorf, Markus, and Wodak Ruth. 2019. 'Austria First 'revisited: A diachronic cross-sectional analysis of the gender and body politics of the extreme right. Patterns of Prejudice 53: 1-19. [CrossRef]

Rush, Michael, and Suleman I. Lazarus. 2018. 'Troubling' Chastisement: A Comparative Historical Analysis of Child Punishment in Ghana and Ireland. Sociological Research Online 23: 177-96. [CrossRef] 
Shutes, Isabel. 2016. Citizenship and Migration. In 2016 Social Advantage and Disadvantage. Edited by Hartley Dean and Lucinda Platt. Oxford: Oxford University Press.

Simon, Patrick, Piché Victor, and Gagnon Amélie. 2015. Social Statistics and Ethnic Diversity. Cross-National Perspectives in Classifications and Identity Politics. IMISCOE Research Series; Cham: Springer.

Song, Miri. 2014. Challenging a Culture of Racial Equivalence. The British Journal of Sociology 65: 107-29. [CrossRef]

Stambolis-Ruhstorfer, Michael. 2013. Labels of love: How migrants negotiate (or not) the culture of sexual identity. American Journal of Cultural Sociology 1: 321-45. [CrossRef]

Supik, Linda. 2014. Statistik und Rassismus. Das Dilemma der Erfassung von Ethnizität. Frankfurt: Campus.

Torry, Malcolm. 2016. Religious advantage and disadvantage. In 2016 Social Advantage and Disadvantage. Edited by Hartley Dean and Lucinda Platt. Oxford: Oxford University Press.

Toscano, Mario Aldo. 2011. Introduzione. In Altre Sociologie: Undici Lezioni Sulla vita e la Convivenza. Milan: Angeli, pp. 9-39.

Triger, Zvi. 2012. Fear of the Wandering Gay: some reflections on citizenship, nationalism and recognition in same-sex relationships. International Journal of Law in Context 8: 268-82. [CrossRef]

Tynes, Brendesha M., Joshua Schuschke, and Safiya Umoja Noble. 2016. Digital intersectionality theory and the black matter movement. In The Intersectional Internet: Race, Sex, Class, and Culture Online. Edited by Safiya Umoja Noble and Brendesha M. Tynes. Berlin: Peter Lang International Academic Publishers.

UNESCO. 1969. 'Four Statements on the Race Question'. Available online: http://unesdoc.unesco.org/images/ 0012/001229/122962eo.pdf (accessed on 11 November 2015).

Vacchelli, Elena, and Eleonore Kofman. 2017. Towards an inclusive and gendered right to the city. Cities 76: 1-3. [CrossRef]

Warming, Hanne. 2019. Trust and Power Dynamics in Children's Lived Citizenship and Participation: The Case of Public Schools and Social Work in Denmark. Children E Society 33: 333-46.

Wodak, Ruth, and Bernd Matouschek. 1993. We are Dealing with People whose Origins One can clearly Tell just by Looking': Critical Discourse Analysis and the Study of Neo-Racism in Contemporary Austria. Discourse E Society 4: 225-48.

Wolfe, Patrick. 2017. Race and Citizenship. Available online: https://cico3dotcom.files.wordpress.com/2016/02/ wolfe-patrick-2004-22race-and-citizenship22.pdf (accessed on 27 January 2017).

Zaslove, Andrej. 2004. Closing the door? The ideology and Impact of Radical Right Populism on Immigration Policy in Austria and Italy. Journal of Political Ideologies 9: 99-118. [CrossRef]

Znaniecki, Florian. 1934. The Method of Sociology. New York: Rinehart.

(C) 2019 by the author. Licensee MDPI, Basel, Switzerland. This article is an open access article distributed under the terms and conditions of the Creative Commons Attribution (CC BY) license (http://creativecommons.org/licenses/by/4.0/). 